magnetic resonance imaging study. Arch Gen Psychiatry 2004; 61 877-89.

28 Elliott R, Rubinsztein JS, Sahakian BJ, Dolan RJ. The neural basis of mood congruent processing biases in depression. Arch Gen Psychiatry 2002; 59: 597-604.

29 Drevets WC. Neuroimaging studies of mood disorders. Biol Psychiatry 2000 48: 813-29.

30 Goodyer IM. Social adversity and mental functions in adolescents at high risk of psychopathology. Position paper and suggested framework for future research. Br J Psychiatry 2002; 181: 383-6.
31 Phillips ML, Drevets WC, Rausch SL, Lane R. Neurobiology of emotion perception I: the neural basis of normal emotion perception. Biol Psychiatry 2003; 54: 504-14.

32 Phillips ML, Drevets WC, Rausch SL, Lane R. Neurobiology of emotion perception II: Implications for major psychiatric disorders. Biol Psychiatry 2003; 54: 515-28.

33 Anand A, Li Y, Wang Y, Wu S, Gao L, Bukhari V, Mathews A, Kalnin M, Lowe MJ. Activity and connectivity of brain mood regulating circuit in depression; a functional magnetic resonance imaging study. Biol Psychiatry 2005; 57: $1079-88$.

\title{
Insane in private dwellings
}

The treatment of the insane in private dwellings, begun ages ago at Gheel, in Belgium, as a place of miraculous healing, entered its modern and rational phase only in the middle of the nineteenth century, when the control and administration of the colony at Gheel passed from the Commune into the hands of the State. A few years later, following the Scottish Lunacy Act of 1857, numbers of the insane were treated in private dwellings in Scotland, and are successfully so treated to-day. From Scotland the system passed to France, and from France to Russia; and from Belgium to Austria, Italy, Holland and Scandinavia. Perhaps its most remarkable development, however, is to be found in Germany to-day, for, whereas in that country there were in 1882 but two small family-colonies for the insane with scarcely more than fifty patients, ten years later there were thirty-two colonies with 1200 patients, and at the end of 1906 there were fifty-one separate colonies with 2400 patients so treated. These different countries adopted the system at the outset for diverse reasons - in Scotland for want of asylum accommodation, in France to relieve their asylums, in Holland entirely as the extension of the policy of the open door, and in Germany from a combination of these reasons; but wherever and however initiated it has been invariably found to be not only a relief to congested asylums, but in itself a valuable therapeutic aid.

\section{Reference}

Cunyngham Brown, R. (1908) The boarding out of the insane in private dwellings. Journal of Mental Science, 54, 532-537. Researched by Henry Rollin, Emeritus Consultant Psychiatrist, Horton Hospital, Epsom, Surrey 